Research Article

\title{
Optimization of Physicochemical Parameters during the Electrocoagulation Cadmium Elimination
}

\author{
Abdelaaziz Aityoub (D), 1,2 Abdesselam Abouelfida, ${ }^{1}$ Abdelaziz Benyaich (D), \\ Abderrahmane Romane, ${ }^{3}$ Mohamed Elmeray, ${ }^{1}$ Rachid Idouhli $\mathbb{D}^{1},{ }^{1}$ Yassine Koumya $\mathbb{D},{ }^{1}$ \\ and Mohyeddine Khadiri $\mathbb{D}^{1}$ \\ ${ }^{1}$ Laboratory Physico-Chemistry of Materials \& Environment (LPCME), Department of Chemistry, Faculty of Sciences Semlallia, \\ University Cadi Ayyad, Marrakech, Morocco \\ ${ }^{2}$ Ecole Normale Superieure, Department of Chemistry, University Cadi Ayyad, Marrakech, Morocco \\ ${ }^{3}$ Laboratory of Applied Chemistry, Department of Chemistry, Faculty of Sciences Semlallia, University Cadi Ayyad, \\ Marrakech, Morocco
}

Correspondence should be addressed to Abdelaaziz Aityoub; aziz.ayoub@gmail.com

Received 18 March 2020; Revised 1 June 2020; Accepted 14 July 2020; Published 11 August 2020

Academic Editor: Shafaqat Ali

Copyright (c) 2020 Abdelaaziz Aityoub et al. This is an open access article distributed under the Creative Commons Attribution License, which permits unrestricted use, distribution, and reproduction in any medium, provided the original work is properly cited.

\begin{abstract}
The increased use of fertilizers from phosphates in agriculture generates water pollution by heavy metals contained in these phosphates at levels higher than the standards. In our study, we used a cadmium nitrate $\mathrm{Cd}\left(\mathrm{NO}_{3}\right)_{2}$ solution to simulate artificially polluted water, whose decontamination efficiency will be evaluated by an electrocoagulation/flotation process. During this work, we aimed to optimize the electrocoagulation process according to the following factors: initial $\mathrm{pH}$ of the solution, density of the electrolysis current, cell time, and nature of the supporting electrolyte and its concentration. The criteria adopted during the optimization of the process are relatively different from those used in similar studies. Indeed, we have tried to achieve maximum efficiency and also seeking to minimize costs and facilitate implementation. We achieved a 98\% Cd removal efficiency from the solution at $\mathrm{pH}=7, J=6.25 \mathrm{~A} / \mathrm{m}^{2}, t=10 \mathrm{~min}$, and $\left[\mathrm{K}_{2} \mathrm{SO}_{4}\right]=0.01 \mathrm{M}$. In addition, during the characterization of the flocs obtained as a supernatant, we first highlighted the presence of $\mathrm{Cd}$ in this gelatinous body and then the relatively easy volatility of $\mathrm{Cd}$ as well as that of aluminum oxide $\left(\mathrm{Al}_{2} \mathrm{O}_{3}\right)$.
\end{abstract}

\section{Introduction}

Heavy metals have recently become one of the major environmental problems for decision makers. Indeed, the demographic evolution in the world was so dazzling that the need to search for more efficient means of production had become paramount. However, this has generated a huge amount of byproducts and more or less harmful waste for human health in the first place and for the environment in general [1-3].

As an example, we can cite the increasing use of industrial fertilizers in agriculture to optimize harvests. These fertilizers are generally obtained from phosphate deposits containing a large proportion of heavy metals [4]. The latter are thus found widespread on the agricultural land and are transported, by leaching effect, towards aquatic resources.

The danger represented by these heavy metals is mainly due to their high bioaccumulation level in living organisms and their nonbiodegradability $[5,6]$. The cleanup usually requires their removal. Several decontamination techniques have been developed in research laboratories and industrial sites in order to eradicate this pollution or at least to minimize their effects. These techniques have been tested by researchers around the world more or less effectively. Mention may be made of, for example, extractions by the chelating agent [7], ozonation process [8], precipitation $[9,10]$, electrodeposition [11], membrane processes, phytoremediation, and adsorption on the nanostructure $[12,13]$. 
Cadmium is one of the most harmful heavy metals for human health in particular and for the environment in general. One source of provenance for this element in the environment is actually the use of chemical phosphate fertilizers [4]. This element is carcinogenic and accumulates in the kidneys [5].

The work presented in this manuscript aimed to treat wastewater, mainly the elimination of cadmium ions by the electrocoagulation process, using two aluminum recovery electrodes. Electrocoagulation is an electrochemical dissolution of a sacrificial anode in order to generate, within the solution, coagulants [14-16]. For an aluminum electrode, electrolysis generates $\mathrm{Al}^{3+}$ ions at the anode, which, depending on the $\mathrm{pH}$ of the medium, hydrolyze and form aluminum hydroxides [17]. The latter contributes to the destabilization of the ions in solutions (as heavy metal cations) and push them to aggregate around these coagulants to form larger and separable agglomerates. These flocs could either precipitate by the gravitational effect or be brought to the surface by a flotation process. The production of oxygen and especially hydrogen bubbles by electrolysis, according to reactions (1) and (2), favored the flotation phenomenon when using a sacrificial aluminum electrode [18-20]. These reactions can occur regardless of the $\mathrm{pH}$ of the medium. At alkaline $\mathrm{pH}$, the production of gas bubbles was done according to the following:

At the cathode,

$$
2 \mathrm{H}_{2} \mathrm{O}_{l}+2 \mathrm{e}^{-} \leftrightharpoons 2 \mathrm{OH}^{-}+\mathrm{H}_{2 g}
$$

At the anode,

$$
4 \mathrm{HO}^{-} \rightleftharpoons \mathrm{O}_{2 g}+2 \mathrm{H}_{2} \mathrm{O}+4 \mathrm{e}^{-}
$$

By filtering, this pasty supernatant can therefore be removed from the contaminated solutions [21].

During this study, we tried to optimize the physicochemical factors that control the electrocoagulation process, namely, the initial $\mathrm{pH}$ of the samples, the density of the electrolysis current, the electrolysis time, and the concentration and nature of the carrier electrolyte used [22, 23]. We also did emphasize the behavior of chloride ions relatively to sulfates during the Cd removal process. EDX and SEM analysis were used to confirm the presence of $\mathrm{Cd}$ ions in the flocs.

\section{Materials and Methods}

The experimental part of our study consisted in determining the effects of each physicochemical parameter, mentioned in the introduction, on the efficiency of the elimination of cadmium from the artificially contaminated water by electrocoagulation proceeding. The common conditions of experimentation during all the tests were

(i) Magnetic stirring speed of $110 \mathrm{rpm}$. This speed made it possible to homogenize the solution while protecting the consistency of the aggregates formed during the coagulation process.

(ii) Temperature controlled by a thermostatic bath at $25^{\circ} \mathrm{C}$.

(iii) The settling time of the solution was $10 \mathrm{~min}$. Two preliminary tests were carried out at 20 and $30 \mathrm{~min}$. The results did not differ from those obtained after $10 \mathrm{~min}$.

2.1. Parameters. The physicochemical parameters controlling the electrocoagulation process are

(i) Initial $\mathrm{pH}$ of the Solution. Various studies have shown that the electrocoagulation process is highly dependent on the $\mathrm{pH}$ [24-26]. It is, above all, the parameter which determines the speciation of metals in a solution and conditions the formation of the coagulant [27].

(ii) Current Density J. It would determine the speed of the electrochemical reaction(s) during the electrocoagulation process, including bubble production [24].

(iii) Electrolysis Time $t$. With the density of current $J$, time will determine the quantity of reactants involved in the process: $\mathrm{Al}^{3+}$ and $\mathrm{HO}^{-}$as the constituents of the coagulant and $\mathrm{H}_{2}$ and $\mathrm{O}_{2}$ as the flotation initiators. Faraday's law $[26,27]$ (equation (1)) gives $u$, the mass per unit area of the electrode dissolved, as a function of the current density $J$ and the duration of the electrolysis $t(\mathrm{~s})$ :

$$
u=\frac{m}{S}=\frac{M(\mathrm{Al})}{n \mathrm{~F}} * J * t,
$$

where $n$ is the number of electrons transferred per $\mathrm{Al}$ atom and $\mathrm{F}$ is the Faraday constant.

(iv) The supporting electrolyte was reported to play an important role in the electrocoagulation process $[24,28]$ : on the one hand, it increases the value of the conductivity of the solution which reduces energy consumption, and on the other hand, it avoids the effect of ion migration, and, thirdly, it can influence the kinetics of certain electrochemical reactions that take place during the electrocoagulation process.

(v) Concentration of the Supporting Electrolyte. The increase in the concentration of ions, resulting from the dissolution of the support electrolyte, will increase the conductivity of the solution and also increase the speed of the processes involving these ions.

Each factor was varied within an interval that we had already set according to preliminary tests and to the literature. Table 1 summarizes the range of variation of the studied factors.

2.2. Chemical Preparation. All reagents used were of analytical quality. We prepared an artificial solution of $\mathrm{Cd}$ 
TABLE 1: Interval of variation of the factors studied.

\begin{tabular}{lc}
\hline Factor & Range of variation \\
\hline $\mathrm{pH}$ initial & 4,7, and 10 \\
Electrolysis time $(\mathrm{min})$ & 5,10, and 20 \\
Current density $\left(\mathrm{A} / \mathrm{m}^{2}\right)$ & $3.125,6.25,12,18.75,37.5,50,70$, and 100 \\
Supporting electrolyte & $\mathrm{KCl}$ and $\mathrm{K}_{2} \mathrm{SO}_{4}$ \\
Supporting electrolyte's concentration $(M)$ & $0.01,0.05$, and 0.1 \\
\hline
\end{tabular}

(10 ppm) by dissolving the corresponding mass of cadmium nitrate in double distilled water. We added the supporting electrolyte used, either $\mathrm{KCl}$ or $\mathrm{K}_{2} \mathrm{SO}_{4}$, by dissolving the appropriate mass of the product in the artificial solution containing the $\mathrm{Cd}^{2+}$ ions. We also prepared a concentrated $\mathrm{HCl}$ solution $(1 \mathrm{M})$ and $\mathrm{NaOH}$ solution $(1 \mathrm{M})$ in order to control the initial $\mathrm{pH}$ of the solution before the electrolysis.

2.3. Apparatus. A $200 \mathrm{ml}$ beaker, containing the electrolyte solution with a cadmium concentration of $10 \mathrm{ppm}$, simulated the reactor. It was equipped with a magnetic bar to ensure mixing of the sample. The stirring speed was adjusted to $110 \mathrm{rpm}$, which facilitates flocculation and prevents shearing of the flocs. Two aluminum electrodes, of planar shape and dimensions (length $L=5 \mathrm{~cm}$, width $l=1.6 \mathrm{~cm}$, thickness $e=0.1 \mathrm{~cm}$ (very small), and area $=2 * 8 \mathrm{~cm}^{2}$ by counting the area of the two sides of each electrode), were emerged in this solution, one serving as a cathode and the other as an anode. They were placed in the cell in parallel and in a vertical position. The interelectrode space was $1 \mathrm{~cm}$ in length. We have chosen this medium value in order to limit the Ohmic drop and according to literature's common electrode interdistance [22]. In fact, the authors have used different values for the distance between the electrodes. Yilmaz et al. [20] worked with $5 \mathrm{~mm}$, Lekhlif et al. [29] and Fekete et al. [21] used $1 \mathrm{~cm}$, and Fekete et al. [21] have tried three values 1,2, and $3 \mathrm{~cm}$. Khandegar et al. have shown that this distance must be sufficiently small for the intensity of the electric field to be sufficient to move the $\mathrm{Al}^{3+}$ ions produced quickly at the anode towards the solution and large enough to allow sufficient residence of the aluminum hydroxides, so that the flocs are formed [30]. This is why authors cite an optimal distance between the electrodes. The flat shape of the electrodes allowed easy mounting and cleaning of the plates.

A generator, used in the continuous mode, brand "ELC" DC POWER SUPPLYALR3003D, provided a potential difference at the terminals of the electrodes varying from 0 to 30 volts. This voltage was measured by a digital voltmeter, and the current of electrolysis was measured by a digital ammeter.

We measured the $\mathrm{pH}$ of the solution using a $\mathrm{pH}$ meter, type HI 2211 Hanna instruments with a combined glass electrode; its calibration was carried out with buffer solutions of $\mathrm{pH} 7$ and 4 . We measured the electrical conductance of the solution using the conductimeter, type Con 510 of EUTECH instruments, equipped with a cell.

2.4. Electrocoagulation. The work carried out included the following stages: (i) Preparation of the artificial electrochemical solution simulating the effluent contaminated with cadmium

(ii) Treatment of the electrode surface by simple manual polishing with the abrasive paper in order to have a homogeneous and clean surface

(iii) Performing the experimental configuration

(iv) Adjusting the initial $\mathrm{pH}$ of the solution using $\mathrm{HCl}$ and $\mathrm{NaOH}$ solutions and noting the initial conductance

(v) Carrying out the corresponding electrolysis with a voltage $U$, a well-determined current density $J$, and for a duration $T$ measured by a chronometer

(vi) Noting, during the treatment, the evolution of the parameters $(U, I)$ without forgetting to note the final conductance and $\mathrm{pH}$ towards the end.

(vii) After electrolysis, the treated solution was left for 10 min to settle, and then it was filtered

(viii) This filtrate was used to measure the cadmium remaining in the solution

2.5. Cadmium Dosage. We determined the initial concentration of cadmium and that remaining in the filtrate by an assay by atomic absorption spectrometry (AAS), of Thermo Scientific brand 3000 A, previously calibrated by high-purity Cd standard solutions.

2.6. Electrocoagulation Efficiency. The efficiency, of the electrocoagulation process during the treatment of the solution, was evaluated by the percentage of cadmium reduction. We calculated this efficiency by the following relation:

$$
E(\%)=\frac{\left(\left(C_{i}-C_{f}\right)\right.}{C_{i}} \times 100,
$$

where $C_{i}$ is the concentration of $\mathrm{Cd}$ in the initial solution and $C_{f}$ is the concentration of $\mathrm{Cd}$ in the final solution after electrolysis and filtration.

\section{Results and Discussion}

The methodology adopted consisted in studying the effect of each parameter considered in order to determine the optimal conditions for eliminating $\mathrm{Cd}$, while keeping the other factors constant. 
3.1. Initial $\mathrm{PHEffect.} \mathrm{The} \mathrm{electrocoagulation} \mathrm{process} \mathrm{strongly}$ depends on solution's $\mathrm{pH}$. It affects Al's speciation, which has a significant influence on the treatment mechanism [31]. It is considered to be a critical factor for the formation of amphoteric hydroxide $\mathrm{Al}(\mathrm{OH})_{3}$, responsible of the formation of flocs [29]. To evaluate the effect of the initial $\mathrm{pH}$ on the efficiency of process and to determine the optimal $\mathrm{pH}$ thereof, we carried out a series of tests with three $\mathrm{pH}$ values: 4,7 , and 10 . The $\mathrm{pH}$ was adjusted before the start of each test with $\mathrm{NaOH}$ and $\mathrm{HCl}$ solutions, while keeping the other operating conditions constant:

(i) $J=6.25 \mathrm{~A} / \mathrm{m}^{2}(\mathrm{I}=10 \mathrm{~mA})$

(ii) $t=10 \mathrm{~min}$

(iii) Supporting electrolyte: potassium chloride with $[\mathrm{KCl}]=0.01 \mathrm{M}$

Also, the final $\mathrm{pH}$ and conductance $\mathrm{G}$ values were noted for each test carried out (A, B, and C); the results obtained are collated in Tables 2 and 3.

As noted in Figure 1, pH had a real effect on the efficiency of Cd extraction from the artificially contaminated solution. Indeed, the variation of the initial $\mathrm{pH}$ of the solution from 4 to 10 led to a variation of this efficiency from $40 \%$ to $95.5 \%$. Between $\mathrm{pH} 4$ and 7 , the elimination efficiency increased greatly with $\mathrm{pH}$; however, beyond $\mathrm{pH} 7$, a certain stability of the latter was noted. This phenomenon can be attributed to the formation of aluminum hydroxide from the $\mathrm{Al}^{3+}$ ions [26] formed at the anode (reaction (5)-(7)) and the $\mathrm{HO}^{-}$ions in the solution (reaction (1)):

At the anode,

$$
\mathrm{Al} \rightleftharpoons \mathrm{Al}^{3+}+3 \mathrm{e}^{-}
$$

In the bulk of the solution,

$$
\mathrm{Al}^{3+}+3 \mathrm{H}_{2} \mathrm{O} \rightleftharpoons \mathrm{Al}(\mathrm{OH})_{3}+3 \mathrm{H}^{+}
$$

The overall:

$$
\mathrm{Al}+3 \mathrm{H}_{2} \mathrm{O} \rightleftharpoons \mathrm{Al}(\mathrm{OH})_{3}+3 \mathrm{H}^{+}+3 \mathrm{e}^{-}
$$

For $\mathrm{pH}$ below $7, \mathrm{HO}^{-}$ions were the limiting reagents and therefore the efficiency increased significantly with $\mathrm{pH}$. This finding was supported by the fact that the $\mathrm{pH}$ at the end of tests $\mathrm{A}$ and $\mathrm{B}$ was higher than the initial $\mathrm{pH}$. On the other hand, beyond $\mathrm{pH} 7$, the efficiency of elimination of $\mathrm{Cd}^{2+}$ ions from the solution was practically constant and maximal. This led us to suppose that the hydroxides formed were sufficient for $\mathrm{Cd}^{2+}$ ions' elimination. This could also be in agreement with the decrease in the final $\mathrm{pH}$ in experiment $\mathrm{C}$. In fact, the $\mathrm{pH}$ of the solution was buffered by the two reactions (7) and (6) which took place in the solution: the hydronium ions, produced by reaction (7), were offset [32] by the hydroxide
TABLE 2: Initial and final solution's $\mathrm{pH}$.

\begin{tabular}{lccc}
\hline & $\mathrm{A}$ & $\mathrm{B}$ & $\mathrm{C}$ \\
\hline $\mathrm{pH}$ initial & 4.17 & 7.09 & 10.34 \\
$\mathrm{pH}$ final & 5.34 & 7.49 & 9.82 \\
$\Delta \mathrm{pH}$ & 1.17 & 0.4 & -0.52 \\
\hline
\end{tabular}

TABLE 3: Initial and final conductance of the solution.

\begin{tabular}{lccc}
\hline & $\mathrm{A}$ & $\mathrm{B}$ & $\mathrm{C}$ \\
\hline $\mathrm{G}$ initial $(\mathrm{mS})$ & 1.71 & 1.88 & 1.74 \\
$\mathrm{G}$ final $(\mathrm{mS})$ & 1.675 & 1.9 & 1.643 \\
$\Delta \mathrm{G}(\mathrm{mS})$ & -0.035 & 0.02 & -0.097 \\
\hline
\end{tabular}

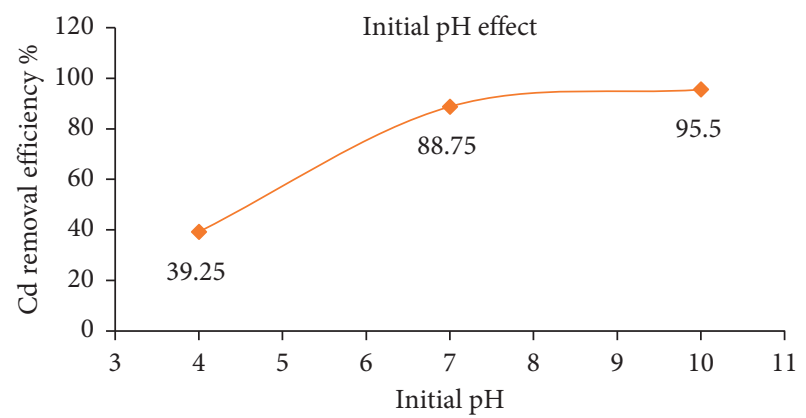

Figure 1: Cd removal efficiency as a function of the initial $\mathrm{pH}$ of the solution.

ions produced in reaction (1). The balance of the two reactions is as follows:

$$
2 \mathrm{Al}+6 \mathrm{H}_{2} \mathrm{O} \rightleftharpoons 2 \mathrm{Al}(\mathrm{OH})_{3}+3 \mathrm{H}_{2}
$$

Some authors had reported that electrocoagulation process, using aluminum electrodes, exhibits a buffering capacity, especially at alkaline conditions [33]. We could also oppose the formation of complex ions $\mathrm{Al}(\mathrm{OH})_{4}^{-}$according to reaction (9), to explain the decrease in $\mathrm{pH}$ in test $\mathrm{C}$ at $\mathrm{pH}$ 10, in accordance with Al's Pourbaix diagram [34]:

$$
\mathrm{Al}(\mathrm{OH})_{3}+\mathrm{HO}^{-} \rightleftharpoons \mathrm{Al}(\mathrm{OH})_{4}^{-}
$$

The latter takes place at a relatively basic pH. Besides, reaction (9) explains the reduction of $\mathrm{pH}$ during experiment $\mathrm{C}$ ( $\mathrm{pH} 10)$. However, depending on the $\mathrm{pH}$ of the aqueous medium, $\mathrm{Al}^{3+}$ and $\mathrm{HO}^{-}$react to form various monomeric species $[14,17,35]$ such as $\mathrm{Al}(\mathrm{OH})^{2+}, \mathrm{Al}(\mathrm{OH})_{2}{ }^{+}$, and $\mathrm{Al}(\mathrm{OH})_{2}{ }^{4+}$ and polymeric species $\mathrm{Al}_{n}(\mathrm{OH})_{3 \mathrm{n}}$. This latter structure contributed to the formation of the gelatinous supernatant above the solution.

As shown in Table 3, the conductance of the solution varied very little during the electrocoagulation process. This means that the ions from the support electrolyte were sufficient to ensure electrical conduction in the solution while avoiding the phenomenon of ion migration. As the quantity used was sufficient, we verified, during the study of the effect of the support electrolyte, if it could be reduced without loss of performance of the whole process. 
In conclusion, the optimal $\mathrm{pH}$ [36] was around 10, but we noticed that a neutral $\mathrm{pH}$ could be appropriate because it was close to the common wastewater's $\mathrm{pH}$ value. In addition, even if the efficiency $(88.25 \%)$ was lower than that at $\mathrm{pH} 10$ (95.5\%), we could hope to improve this efficiency when optimizing the other factors. Hence, the following experiments were carried out at $\mathrm{pH} 7$.

3.2. Effect of Electrolysis Time. One of the most important parameters in this study was the electrolysis time $t$ [37]. To study its effect on the efficiency of this process, we examined a series of treatment trials: the first lasting $5 \mathrm{~min}$, the second $10 \mathrm{~min}$, and the last $20 \mathrm{~min}$, while keeping the other operating parameters constant $\left(\mathrm{pH}=7, J=6.25 \mathrm{~A} / \mathrm{m}^{2}\right.$, and $[\mathrm{KCl}]=0.01 \mathrm{M})$.

The results obtained are expressed graphically in Figure 2.

The results corresponding to the evolution of the initial $\mathrm{pH}$ and of the conductance $\mathrm{G}$ of the solution, during the experiment, are presented, respectively, in Tables 4 and 5 .

As we can see in Figure 2, the efficiency of cadmium removal increased significantly over time (from test A to test B) and then stabilized around $87 \%$ beyond 10 min with a slight downward trend ( 88.75 in test B to $86 \%$ in test C). This dependence on time led us to kinetic considerations where we identified two phases:

(i) A first phase (between A and B), where the increase was proportional to time, which made us suggest that the limiting parameter was brought in as time was increased: it was probably a product of electrolysis and which participated in the formation of flocs. It was either the $\mathrm{Al}^{3+}$ ions or the hydroxide ions or both.

(ii) A second period (between B and C) where time has practically no effect on the efficiency of the removal of $\mathrm{Cd}^{2+}$ ions from the artificial solution. This led us to suppose that it was the transformation (the formation of coagulants and then flocs) itself which was limiting in this second phase: all the reagents were therefore present in more than sufficient quantity, and thus the elimination efficiency was controlled by the transformations that would operate on the reactants.

The evolution of the conductance of the solution is presented in Table 5 . The variation was less than $2 \%$ in the three experiments. This confirmed that the supporting electrolyte was in enough quantity so as to minimize ion's migration.

The examination of the evolution of the initial $\mathrm{pH}$ (Table 4) which increased slightly at the end of the process for the three tests (A, B, and C) showed that the contribution of the hydroxide ions was made almost in the same way during the three tests, and then it was the contribution of $\mathrm{Al}^{3+}$ ions which was probably responsible for the efficiency evolution in the first phase (from A to B). The amplitude of the $\mathrm{pH}^{\prime} \mathrm{s}$ variation revealed that the solution was still buffered by reaction (8) mentioned above.

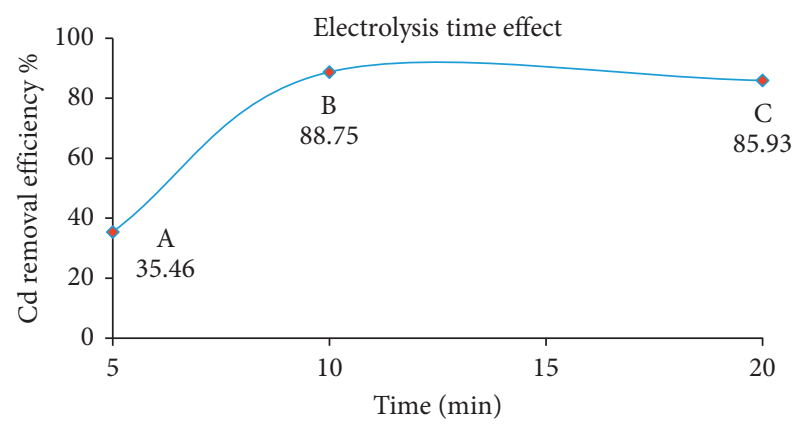

Figure 2: Effect of electrolysis time on Cd removal efficiency.

TABLE 4: Initial and final solution's $\mathrm{pH}$.

\begin{tabular}{lccc}
\hline & A & B & C \\
\hline $\mathrm{pH}$ initial & 7.27 & 7.09 & 7.36 \\
$\mathrm{pH}$ final & 7.56 & 7.49 & 7.67 \\
$\Delta \mathrm{pH}$ & 0.29 & 0.4 & 0.31 \\
\hline
\end{tabular}

TABLE 5: Initial and final conductance of the solution.

\begin{tabular}{lccc}
\hline & A & B & C \\
\hline G initial $(\mathrm{mS})$ & 1.71 & 1.88 & 1.717 \\
$\mathrm{G}$ final $(\mathrm{mS})$ & 1.697 & 1.9 & 1.684 \\
$\Delta \mathrm{G}(\mathrm{mS})$ & -0.013 & 0.02 & -0.033 \\
\hline
\end{tabular}

Some authors have suggested that aluminum hydroxides, freshly formed, were best suited to form aggregates by adsorption of soluble ions and/or trap colloidal particles in suspension in the solution $[24,27,28]$. This property was due to their small size and consequently their large specific surface. Indeed, at the beginning of the experiment, the aluminum hydroxides formed find $\mathrm{Cd}^{2+}$ ions very close to the electrode: the time between their formation and that of the interaction with the pollutants is very short and therefore their activity is maximum. But as time passed, the concentration of $\mathrm{Cd}^{2+}$ ions around the electrode decreased and it took time, so that these two entities might diffuse towards each other to interact. Hence, the hydroxides were no longer fresh, and therefore their activity was decreased. As a result, the efficiency of removing $\mathrm{Cd}$ ions decreased as the electrolysis time increased [17]. The optimal time corresponding to the maximum removal efficiency of the pollutant was very dependent on the distance between the electrodes. The lower the latter, the shorter the time to reach the maximum efficiency.

Thus, the optimal electrolysis time was around $10 \mathrm{~min}$. As time was closely linked to the cost of the process, it was wise to choose the shortest acceptable time.

3.3. Effect of Current Density J. Current density was a critical parameter in the electrocoagulation process since it could be controlled directly and determine the rate of the electrochemical reactions.

We studied the influence of the intensity of the current on the elimination efficiency of cadmium. For this, we 
carried out a series of tests by applying current intensities of $5.10,20.30,40,60,80,112$, and $160 \mathrm{~mA}$. Knowing the surface of the electrode, worth $S=16 \mathrm{~cm}^{2}$, the current densities $J$ corresponded, respectively, to $3.125,6.25,12,18.75,37.5,50$, 70 , and $100 \mathrm{~A} / \mathrm{m}^{2}$ (while always keeping the other operating conditions constant: $\mathrm{pH}=7, t=10 \mathrm{~min}$, and $[\mathrm{KCl}]=0.01 \mathrm{M}$ ). Tests B, G, and I were repeated in order to evaluate the passivation effect.

The results in Table 6 are illustrated in Figure 3.

Tables 7 and 8 present the initial and final $\mathrm{pH}$ and the conductance value during electrolysis for each test carried out.

The evolution of the $\mathrm{Cd}^{2+}$ ions' elimination efficiency, by the electrocoagulation process, as a function of the density of the current, presented a very uneven form:

(i) Increasing phases relatively to $J$ between $A$ and $B, D$, and $\mathrm{E}$ and finally $\mathrm{F}$ and $\mathrm{H}$

(ii) Stationary phase between $\mathrm{E}$ and $\mathrm{F}$

(iii) Decreasing phase between $\mathrm{B}$ and $\mathrm{D}$, as well as $\mathrm{H}$ and I

This led us to suppose that the studied system undergoes a structural transformation during this operation. This modification was strongly dependent on the density of the current and consequently would concern the state of the metal/solution's interphase. This irregular development was possibly caused by two factors: the first is the phenomenon of passivation of aluminum electrodes, reported by several authors $[19,32,38]$; the second is due to the chloride ions from the $\mathrm{KCl}$ supporting electrolyte [39-41]. Several authors have suggested that aluminum undergoes a passivation phenomenon due to the formation of a layer of $\mathrm{Al}_{2} \mathrm{O}_{3}$ oxide on the surface of the metal. This layer is not, however, permanent. Indeed, it is followed by a phase of depassivation. The latter is as important as the medium is rich in chloride ions which contribute to the degradation of this layer of alumina by their pitting $[22,42,43]$ corrosive power. This was later verified during the study of the supporting electrolyte effect on the electrocoagulation process.

In order to reduce the phenomenon of passivation of the electrodes, several precautions have been taken:

(i) Permutation of the roles of the electrodes, especially during redone experiments (tests B, G, and I);

(ii) Mechanical cleaning of electrodes, between two experiments, by rubbing them with the sandpaper, followed by abundant washing with distilled water. This last operation is cited by authors as the most effective method for preserving electrodes [44].

The $\mathrm{pH}$ evolution during the electrocoagulation process, as reported in Table 7 , was very small (max around $8 \%$ ). At $\mathrm{pH} 7$, the buffer effect is mainly due to reaction (7) which leads to aluminum hydroxide formation. Also, the solution's conductance remains relatively stable during the process: the electrocoagulation process does not change the electrolyte consistency of the solution.

The reasonable choice of the current density therefore had to meet the two criteria: cost and efficiency. We had chosen the value of $6.25 \mathrm{~A} / \mathrm{m}^{2}$ for this purpose and above all to avoid the area where we had observed the reduction of the efficiency of removing $\mathrm{Cd}$ ions.

3.4. Supporting Electrolyte Effect. To study the effect of supporting electrolyte on the elimination of cadmium by the electrocoagulation process, we used two salts: potassium chloride $\mathrm{KCl}$, whose chloride ions are suspected to have a disruptive effect, and potassium sulfate $\mathrm{K}_{2} \mathrm{SO}_{4}$, which is free from chloride ions.

3.5. Potassium Chloride $\mathrm{KCl}$. The presence of chloride ions in the solution has been reported to decrease passivation of the electrode surface and thereby increase the efficiency of the electrocoagulation processes [45]. To study their effect, we carried out a series of tests with different $\mathrm{KCl}$ concentrations $(0.01,0.05$, and $0.1 \mathrm{M})$, while keeping the other parameters constant $\left(\mathrm{pH}=7, t=10 \mathrm{~min}\right.$, and $\left.J=6.25 \mathrm{~A} / \mathrm{m}^{2}\right)$. Figure 4 represents the results obtained.

Tables 9 and 10 group together the initial and final values of the $\mathrm{pH}$ and the conductance $\mathrm{G}$ of the electrolytic solution.

The concentration of $\mathrm{KCl}$, the supporting electrolyte, has a great influence on the efficiency of elimination of the $\mathrm{Cd}^{2+}$ ions contained in the solution. These two quantities are inversely proportional. Indeed the latter varies from $95 \%$ for $[\mathrm{KCl}]=0.01 \mathrm{M}$ to $42 \%$ for $0.1 \mathrm{M}$. This allowed us to suggest that in addition to their role in the electrical conduction of the solution, the ions of the supporting electrolyte had an active role during the electrocoagulation process. In addition, this role is in competition with the extraction of $\mathrm{Cd}$ ions because a decrease in the efficiency of their elimination was observed when the concentration of the electrolyte increased. Several authors [29] have attributed this reduction to the complexation of $\mathrm{Al}^{3+}$ ions (reaction (10)) or their hydrates (reaction (11)) by ligands $\mathrm{L}^{-}$, including the chloride ions as [32]

$$
\begin{gathered}
\mathrm{Al}^{3+}+n \mathrm{Cl}^{-} \rightleftharpoons\left[\mathrm{Al}(\mathrm{Cl})_{n}\right]^{(3-n)+} \\
\mathrm{Al}\left(\mathrm{H}_{2} \mathrm{O}\right)_{m(\mathrm{aq})}^{3+}+n \mathrm{Cl}_{(\mathrm{aq})}^{-} \rightleftharpoons\left[\mathrm{Al}\left(\mathrm{H}_{2} \mathrm{O}\right)_{m-n} \mathrm{Cl}_{n}\right]_{(\mathrm{aq})}^{(3-n)+}+n \mathrm{H}_{2} \mathrm{O}_{(\mathrm{aq})}
\end{gathered}
$$

These cations will not be available to participate in the electrocoagulation process and therefore contribute to reducing the efficiency of elimination. Besides that, other authors have highlighted the formation in the aqueous solution of cadmium complexes with the ligands $\mathrm{Cl}^{-}$ according to the global reaction (12) [46-48]:

$$
\mathrm{Cd}^{2+}+n \mathrm{Cl}^{-} \rightleftharpoons \mathrm{Cd}(\mathrm{Cl})_{n}^{(2-n)+}, \quad \text { where } n=1,2,3 \text {, and } 4 \text {. }
$$

Stability constants $K_{n}$ for $\mathrm{Cd}^{2+}$-chloride systems in water were calculated [47] and are, respectively, 22.3, 60, 26, and $10^{-0.2}$. On the other hand, the variation in conductance, although small, increases from test $\mathrm{A}$ to test $\mathrm{C}$. This allowed us to assume that the electrolyte ions are actually engaged 
TABLE 6: The Cd removal efficiency as a function of the current density $J$.

\begin{tabular}{lcccc}
\hline Test & Concentration $(\mu \mathrm{g} / \mathrm{ml})$ & $J\left(\mathrm{~A} / \mathrm{m}^{2}\right)$ & \% Cd removal & \% Cd removal $(\mathrm{mean})$ \\
\hline $\mathrm{A}$ & 4.5916 & 3.125 & 54.08 & 54.08 \\
$\mathrm{~B}$ & 0.66941 & 6.25 & 90 & 88.75 \\
& 0.60032 & 12.5 & 57.5 & 52.79 \\
$\mathrm{C}$ & 4.72025 & 18.75 & 52.79 & 44.14 \\
$\mathrm{D}$ & 5.5852 & 25 & 44.14 & 70.61 \\
$\mathrm{E}$ & 2.9389 & 37.5 & 70.61 & 74.66 \\
$\mathrm{~F}$ & 2.5337 & 50 & 74.66 & 92.31 \\
$\mathrm{G}$ & 0.3344 & & 96.65 & 95.2 \\
& 1.20257 & 70 & 87.97 & 74.02 \\
$\mathrm{H}$ & 0.4758 & 100 & 95.2 & 69.51 \\
\end{tabular}

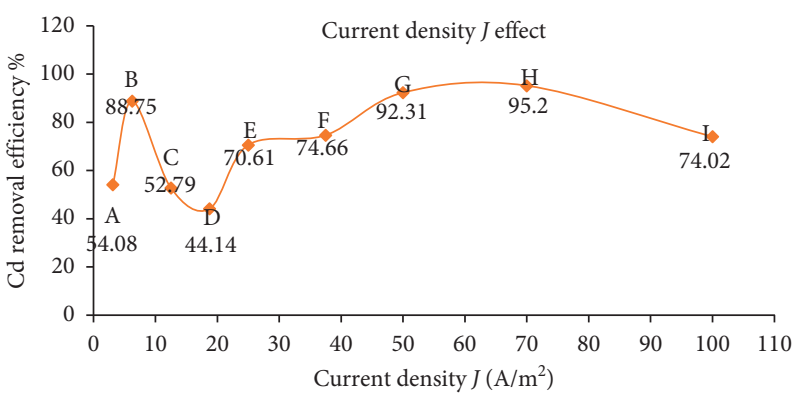

FIgURE 3: Effect of current density $J$ on the efficiency of electrocoagulation.

TABLE 7: Solution's pH evolution.

\begin{tabular}{lccccccccc}
\hline & $\mathrm{A}$ & $\mathrm{B}$ & $\mathrm{C}$ & $\mathrm{D}$ & $\mathrm{E}$ & $\mathrm{F}$ & $\mathrm{G}$ & $\mathrm{H}$ & $\mathrm{I}$ \\
\hline $\mathrm{pH}$ initial & 7.09 & 7.09 & 7.69 & 7.03 & 7.13 & 7.08 & 7.06 & 7.23 & 7 \\
$\mathrm{pH}$ final & 6.71 & 7.49 & 7.38 & 7.01 & 7.36 & 7.3 & 7.65 & 7.67 & 6.66 \\
$\Delta \mathrm{pH}$ & -0.38 & 0.4 & -0.31 & -0.02 & 0.23 & 0.22 & 0.59 & 0.44 & -0.34 \\
\hline
\end{tabular}

TABLE 8: Variation of the conductance of the solution.

\begin{tabular}{lccccccccc}
\hline & A & B & C & D & E & F & G & H & I \\
\hline G initial $(\mathrm{mS})$ & 1.761 & 1.88 & 1.474 & 1.73 & 1.401 & 1.719 & 1.77 & 1.719 & 1.783 \\
G final $(\mathrm{mS})$ & 1.758 & 1.9 & 1.451 & 1.72 & 1.386 & 1.7 & 1.73 & 1.69 & 1.762 \\
$\Delta \mathrm{G}(\mathrm{mS})$ & -0.003 & 0.02 & -0.023 & -0.01 & -0.015 & -0.019 & -0.04 & -0.029 & -0.021 \\
\hline
\end{tabular}

during the process, in agreement with the two preceding reactions (10) and (11).

This observation is supported by the slight increase in $\mathrm{pH}$ at the end of experiments A, B, and C. Indeed a number of $\mathrm{HO}^{-}$had gone into the solution instead of forming aluminum hydroxides, and thus contribute to the rising of $\mathrm{pH}$ and reducing the elimination efficiency. But, this proportion of $\mathrm{HO}^{-}$involved cannot explain this significant drop in the Cd ions' removal efficiency from the solution. Hence, the magnitude of the variation in the efficiency of elimination of Cd ions from the solution, which decreased from $92.31 \%$ to $41.22 \%$, suggested that it is rather the complexation of $\mathrm{Cd}$ ions by chlorides that predominates in determining the extraction efficiency of pollutants.
3.6. Potassium Sulfate $\mathrm{K}_{2} \mathrm{SO}_{4}$. We carried out a series of tests with three different concentrations of $\mathrm{K}_{2} \mathrm{SO}_{4}(0.01,0.05$, and $0.1 \mathrm{M})$, while keeping the other parameters constant $(\mathrm{pH}=7$, $t=10 \mathrm{~min}$, and $J=6.25 \mathrm{~A} / \mathrm{m}^{2}$ ).

Figure 5 represents the percentage of removed $\mathrm{Cd}$, relative to its initial value, after treatment of the solution, as a function of the concentration of the supporting electrolyte.

Tables 11 and 12 group together the initial and final values of the $\mathrm{pH}$ and of the conductance $\mathrm{G}$ of the electrolytic solution in the case of $\mathrm{K}_{2} \mathrm{SO}_{4}$ as the supporting electrolyte.

The use of $\mathrm{K}_{2} \mathrm{SO}_{4}$ as a supporting electrolyte slightly influenced the efficiency of elimination of $\mathrm{Cd}^{2+}$ ions, as depicted in Figure 5. This effect is negative because a 


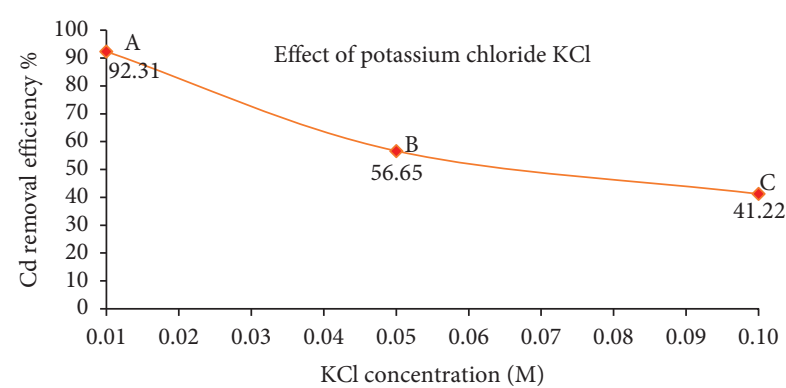

FIgURE 4: Effect of potassium chloride $\mathrm{KCl}$ on electrocoagulation.

TABLE 9: Initial and final $\mathrm{pH}$ of the solution (case of the $\mathrm{KCl}$ supporting electrolyte).

\begin{tabular}{lccc}
\hline & $\mathrm{A}$ & $\mathrm{B}$ & $\mathrm{C}$ \\
\hline $\mathrm{pH}$ initial & 7.06 & 7.03 & 7.04 \\
$\mathrm{pH}$ final & 7.65 & 7.33 & 7.37 \\
$\Delta \mathrm{pH}$ & 0.59 & 0.3 & 0.33 \\
\hline
\end{tabular}

TABle 10: The initial and final values of the conductance of the solution (case of $\mathrm{KCl}$ ).

\begin{tabular}{lccc}
\hline & A & B & C \\
\hline $\mathrm{G}$ initial $(\mathrm{mS})$ & 1.77 & 7.15 & 13.05 \\
$\mathrm{G}$ final $(\mathrm{mS})$ & 1.73 & 7.05 & 12.89 \\
$\Delta \mathrm{G}(\mathrm{mS})$ & -0.04 & -0.1 & -0.16 \\
\hline
\end{tabular}

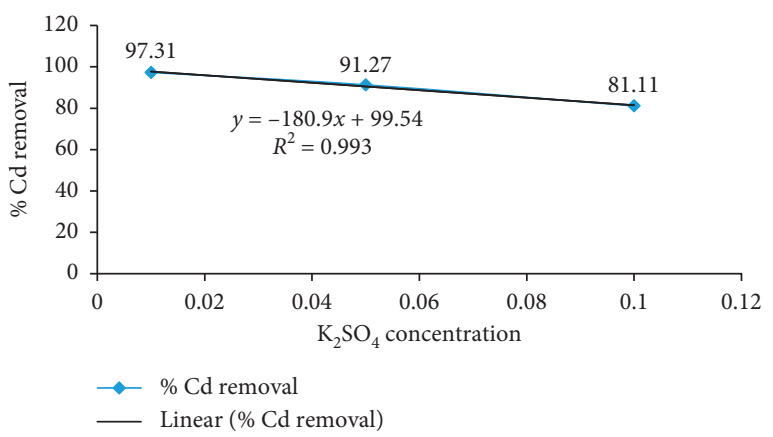

Figure 5: Cd removal efficiency depending on the concentration of the supporting electrolyte.

TABLE 11: Evolution of the $\mathrm{pH}$ of the solution (case of the supporting electrolyte $\mathrm{K}_{2} \mathrm{SO}_{4}$ ).

\begin{tabular}{lccc}
\hline & $\mathrm{A}$ & $\mathrm{B}$ & $\mathrm{C}$ \\
\hline $\mathrm{pH}$ initial & 7.02 & 7.06 & 7.01 \\
$\mathrm{pH}$ final & 7.74 & 8.14 & 8.03 \\
$\Delta \mathrm{pH}$ & 0.72 & 1.08 & 1.02 \\
\hline
\end{tabular}

decrease in this effectiveness was observed from $97 \%$ to $81 \%$ when the concentration increased from 0.01 to $0.1 \mathrm{M}$.

The linearity shape, between the percentage of $\mathrm{Cd}$ elimination and the concentration of the supporting
TABLE 12: Variation of the conductance of the solution (case of $\mathrm{K}_{2} \mathrm{SO}_{4}$ ).

\begin{tabular}{lccc}
\hline & A & B & C \\
\hline G initial $(\mathrm{mS})$ & 2.77 & 11.19 & 21.7 \\
G final $(\mathrm{mS})$ & 2.74 & 10.97 & 21.2 \\
$\Delta \mathrm{G}(\mathrm{mS})$ & -0.03 & -0.22 & -0.5 \\
\hline
\end{tabular}

electrolyte $\mathrm{K}_{2} \mathrm{SO}_{4}$ (Figure 5), suggested that only one phenomenon, linked to the $\mathrm{SO}_{4}{ }^{2-}$ ions, took place during the electrocoagulation process. It was a phenomenon in competition with the elimination of $\mathrm{Cd}^{2+}$ ions as revealed by the decrease in the latter. As some authors have mentioned that the $\mathrm{Cd}^{2+}$ ions form complexes with sulfate ions [48] in addition to the $\mathrm{CdSO}_{4}$ precipitate.

The presence of sulfate ions was less inhibiting than that of chloride ones on the decontamination efficiency of the simulated effluent. To illustrate this statement, we have compared the cadmium elimination efficiency as a function of the current density $J$ during treatment in a medium containing potassium sulfates as the supporting electrolyte and those obtained previously in the case of potassium chloride. We had worked under unfavorable conditions to visualize the reducing effect of the efficiency of removal of $\mathrm{Cd}$ ions from the solution. The concentration of supporting electrolytes was $0.1 \mathrm{M}$, and the current density was greater than $6.25 \mathrm{~A} / \mathrm{m}^{2}$. The results obtained are illustrated in Figure 6.

A comparative study of the two curves in Figure 6 allowed us to conclude that it was the presence of chloride ions which was responsible for the reduction in the efficiency of $\mathrm{Cd}^{2}+$ ion elimination. This influence was probably manifested in, at least, two antagonistic aspects:

(i) One was stimulating elimination as for the sulfate ions (ascending phase for $J$ varying from 12.5 to $37.5 \mathrm{~A} / \mathrm{m}^{2}$ )

(ii) The other, presenting an inhibitory effect contrary to sulfate ions, was manifested by a decrease in this efficiency (for $J$ ranging from 37.5 to $100 \mathrm{~A} / \mathrm{m}^{2}$ )

In view of the results obtained, we opted for $\mathrm{K}_{2} \mathrm{SO}_{4}$ as a supporting electrolyte at a concentration of $0.01 \mathrm{M}$.

In conclusion, the optimal conditions for the removal of $\mathrm{Cd}^{2+}$ ions from the artificially contaminated solution, by electrocoagulation process, were

(i) $\mathrm{pH}=7$

(ii) $T=10 \mathrm{~min}$

(iii) $J=6.25 \mathrm{~A} / \mathrm{m}^{2}$

(iv) $\mathrm{K}_{2} \mathrm{SO}_{4}$ supporting electrolyte at $0.01 \mathrm{M}$

Under these conditions, an elimination efficiency of 97.31\% was obtained.

As can be seen in Table 13, compared to similar works, we have achieved a relatively effective elimination, but with a shorter treatment time and a lower current density. These two objectives were among our optimization criteria. 


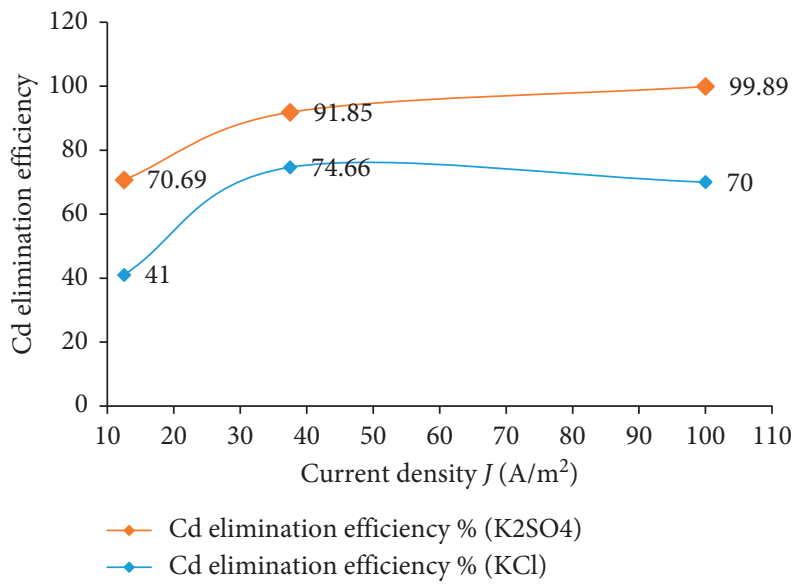

Figure 6: Comparison between the effects of the two supporting electrolytes.

TABLE 13: Cd removal efficiency and operating conditions in the EC process (similar works).

\begin{tabular}{|c|c|c|c|c|c|c|c|}
\hline & Electrode & Interelectrode distance $(\mathrm{cm})$ & $J$ current density & $p \mathrm{H}$ & $T(\min )$ & Removal efficiency (\%) & Reference \\
\hline Vasudevan et al. & $\mathrm{Al}$ & 0.5 & $\begin{array}{l}10 \mathrm{~A} / \mathrm{m}^{2} \\
50 \mathrm{~A} / \mathrm{m}^{2}\end{array}$ & 7 & 5 & $\begin{array}{l}92.4 \\
97.9\end{array}$ & [49] \\
\hline Chien et al. & $\mathrm{Al}$ & 0.5 & $20 \mathrm{~A} / \mathrm{m}^{2}$ & 7 & 30 & 96.8 & [50] \\
\hline Yilmaz et al. & $\mathrm{Al}$ & 0.5 & $15 \mathrm{~A} / \mathrm{m}^{2}$ & 6 & 30 & 99 & {$[20]$} \\
\hline Hung et al. & $\mathrm{Al}-\mathrm{Cgr}$ & 1 & $22 \mathrm{~A} / \mathrm{m}^{2}$ & 11 & 10 & 99.5 & {$[50]$} \\
\hline Kobya et al. & $\mathrm{Fe}$ & 1 & $30 \mathrm{~A} / \mathrm{m}^{2}$ & $8-10$ & 80 & 99.4 & [51] \\
\hline Aityoub et al. & $\mathrm{Al}$ & 1 & $10 \mathrm{~A} / \mathrm{m}^{2}$ & 7 & 10 & 97.31 & This work \\
\hline
\end{tabular}

3.7. Characterization of Flocs. To reveal the presence of chloride and the sulfate ions in the flocs resulting from the electrocoagulation, we had carried out an analysis of the latter by scanning microscopy (SEM) of the gel obtained at the end of the electrolysis on the surface of the solution and also that of the solid obtained during the drying of this gel by moderately heating it.

Two experiments were carried out under optimal conditions $\left(\mathrm{pH}=7, T=10 \mathrm{~min}, J=6.25 \mathrm{~A} / \mathrm{m}^{2}\right.$, and $\left.C=0.01 \mathrm{M}\right)$, each with a supporting electrolyte $\left(\mathrm{KCl}\right.$ or $\left.\mathrm{K}_{2} \mathrm{SO}_{4}\right)$. We thus, recovered four samples: two gelatinous and two in the solid state.

The four samples were then analyzed, by MEB and EDX, to determine their structure and composition. In Table 14, we have reported all the results obtained (photo, spectrum, and composition).

(i) First, we noticed that all the samples had an amorphous structure.

(ii) The two gelatinous samples 1 and 2 consist mainly of aluminum and oxygen, as shown by their atomic composition ( $68 \%$ in oxygen and $25 \%$ in aluminum for the first and $70 \%$ in $\mathrm{O}$ and $70 \%$ in $\mathrm{Al}$ for the second).

(iii) For the two solid samples 3 and 4, obtained by drying the electrolyzed solution on a hot plate, the main remark was the absence of $\mathrm{Cd}$ and the reduction of the $\mathrm{Al}$ and $\mathrm{O}$ content. This suggested that these structures are likely to evaporate at a relatively high temperature (about $120^{\circ} \mathrm{C}$ in our study). We could advance as the first conclusion that the interactions in the process of electrocoagulation flocculation were of the physical type since even at this "low" temperature, these interactions were broken. On the other hand, as has been demonstrated by other authors, cadmium was volatile $[52,53]$, and its transfer could take place by air (propagation of the pollution around the garbage incinerators) [54].

(iv) We also observed that the amount of $\mathrm{K}$ and $\mathrm{Cl}$ increased sharply in sample 3 and that of $\mathrm{K}$ and $\mathrm{S}$ in sample 4 . This was due to the recovery of the ions in the solution in the form of a solid, namely, $\mathrm{KCl}$ and $\mathrm{K}_{2} \mathrm{SO}_{4}$.

(v) For Cd ions, on the other hand, they were absent in the analysis: they were not recovered after evaporation of the solution.

(vi) The amount of cadmium removal by the aluminum atom was to the advantage of the medium containing the chloride compared to the sulfates. Indeed, the ratio of atomic percentages $\% \mathrm{Cd} / \% \mathrm{Al}$ was equal to 0.0075 for $\mathrm{Cl}^{-}$and 0.0050 for $\mathrm{SO}_{4}{ }^{2-}$.

Based on these results, we could not explain the reduction in the efficiency of elimination of $\mathrm{Cd}^{2+}$ as a function of the concentration of $\mathrm{Cl}^{-}$: there must be other phenomena linked to the presence of chlorides. Some authors have reported the formation of cadmium complexes with chlorides as ligands [48]: $\mathrm{CdCl}^{+}, \mathrm{CdCl}_{2}, \mathrm{CdCl}_{3}{ }^{-}$, and $\mathrm{CdCl}_{4}{ }^{2-}$. 
TABLE 14: Summary of data collected by EDX and SEM analysis.

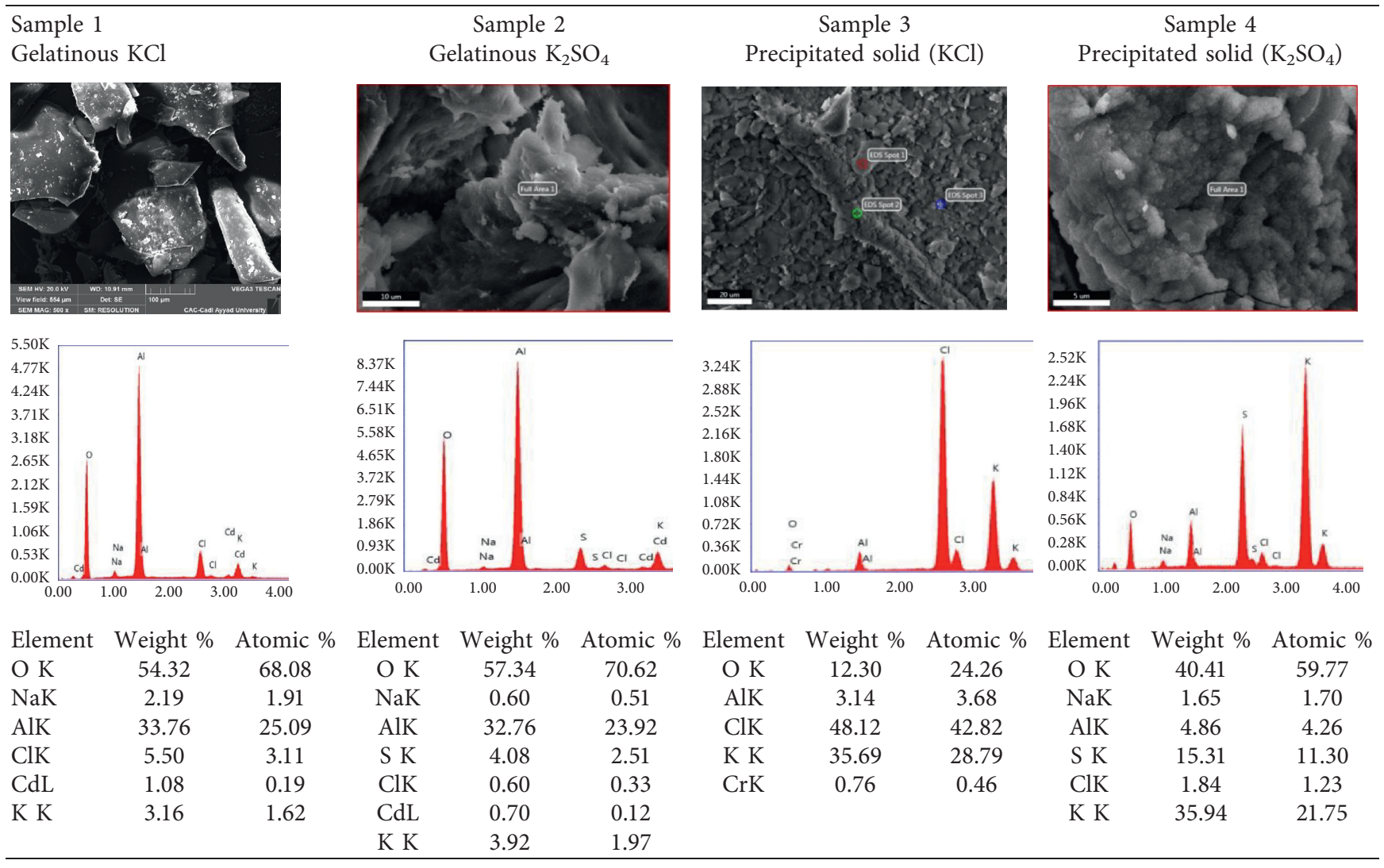

The speciation of $\mathrm{Cd}$ in the seawater was reported by Robert P. Mason [46, 48] as 2.9\% for $\mathrm{Cd}^{2+}, 39.8 \%$ for $\mathrm{CdCl}^{+}, 28.9 \%$ for $\mathrm{CdCl}_{2}, 15.1 \%$ for $\mathrm{CdCl}_{3}{ }^{-}$, and $3.3 \%$ for $\mathrm{CdCl}_{4}{ }^{2-}$. We could therefore assume that it was perhaps the formation of these complexes which entered into competition with electrocoagulation and caused the efficiency to be very reduced in a medium relatively rich in chlorides. Indeed, the

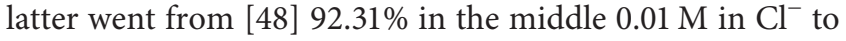
$41.22 \%$ for $\left[\mathrm{Cl}^{-}\right]=0.1 \mathrm{M}$.

\section{Conclusion}

An aqueous solution of $\mathrm{Cd}(\mathrm{NO})_{3}$ was used to simulate an artificially contaminated effluent.

The decontamination by electrocoagulation/flocculation enabled us to achieve an elimination at $97.31 \%$.

The water reduction reaction generated the hydrogen bubbles, which contributed to the flotation of the formed flocs.

The quest for this result was made through the study of the effects of the factors $\mathrm{pH}$, time, current density, concentration, and supporting electrolyte's nature.

The use of a supporting electrolyte has reduced the effectiveness of decontamination.

This negative effect was due, among other causes, to parasitic reactions which compete with decontamination by forming complexes with $\mathrm{Cd}$ ions and hence keeps them in the solution and therefore reduces the efficiency of their elimination. However, its use was necessary in order to prevent the $\mathrm{Al}^{3+}$ ions from being engaged to ensure electrical conduction in the solution (minimum concentration).

Chloride ions were more unfavorable than sulfate ions for decontamination by electrocoagulation.

The optimization of this decontamination obeyed the three criteria: the cost of the operation (minimum time and minimum $J$ ), the ease of startup (neutral $\mathrm{pH}$ ), and the efficiency (maximum elimination).

We were able to reach an efficiency of $97.31 \%$ under conditions which were not very drastic: $\mathrm{pH}=7, T=10 \mathrm{~min}$, $J=6.25 \mathrm{~A} / \mathrm{m}^{2}$, and $C=0.01 \mathrm{M}$ of $\mathrm{K}_{2} \mathrm{SO}_{4}$.

We achieved an efficiency of $99.89 \%$ but under nonoptimal conditions (experience of comparison between $\mathrm{KCl}$ and $\mathrm{K}_{2} \mathrm{SO}_{4}$ ).

SEM and EDX analysis of the supernatant confirmed the presence of $\mathrm{Cd}$ ions in this gelatinous compound.

Lastly, we also highlighted the volatility of aluminum oxide $\left(\mathrm{Al}_{2} \mathrm{O}_{3}\right)$ as well as of the $\mathrm{Cd}$ ions linked to it, at temperatures approaching $120^{\circ} \mathrm{C}$.

\section{Data Availability}

All the data are in the possession of the authors and would be provided if requested.

\section{Conflicts of Interest}

The authors declare that they have no conflicts of interest. 


\section{References}

[1] K. Khan, Y. Lu, H. Khan et al., "Health risks associated with heavy metals in the drinking water of Swat, northern Pakistan," Journal of Environmental Sciences, vol. 25, no. 10, pp. 2003-2013, 2013.

[2] N. Soltani, B. Keshavarzi, F. Moore et al., "Ecological and human health hazards of heavy metals and polycyclic aromatic hydrocarbons (PAHs) in road dust of Isfahan metropolis, Iran," Science of The Total Environment, vol. 505, pp. 712-723, 2015.

[3] C. Dassonville, C. Mandin, and S. Kirchner, "Pollutions à l'intérieur des espaces clos: sources, niveaux et impact sanitaire. Volet 2: polluants chimiques," Archives des Maladies Professionnelles et de l'Environnement, vol. 75, no. 6, pp. 594-606, 2014.

[4] T. L. Roberts and Cadmium, "Cadmium and phosphorous fertilizers: the issues and the science," Procedia Engineering, vol. 83, pp. 52-59, 2014.

[5] S.-H. Xie, A.-L. Liu, Y.-Y. Chen et al., "DNA damage and oxidative stress in human liver cell L-02 caused by surface water extracts during drinking water treatment in a waterworks in China," Environmental and Molecular Mutagenesis, vol. 51, 2009.

[6] B. V. Tangahu, S. R. S. Abdullah, H. Basri, M. Idris, N. Anuar, and M. Mukhlisin, "A review on heavy metals (As, $\mathrm{Pb}$, and $\mathrm{Hg}$ ) uptake by plants through phytoremediation," International Journal of Chemical Engineering, vol. 2011, Article ID 939161, 31 pages, 2011.

[7] B. Mohanty and A. B. Mahindrakar, "Removal of heavy metal by screening followed by soil washing from contaminated soil," International Journal of Technology and Engineering System, vol. 2, pp. 290-293, 2011.

[8] Z. Honarmandrad, N. Javid, and M. Malakootian, "Efficiency of ozonation process with calcium peroxide in removing heavy metals $(\mathrm{Pb}, \mathrm{Cu}, \mathrm{Zn}, \mathrm{Ni}, \mathrm{Cd})$ from aqueous solutions," SN Applied Sciences, vol. 2, p. 703, 2020.

[9] M. A. Barakat, "New trends in removing heavy metals from industrial wastewater," Arabian Journal of Chemistry, vol. 4, no. 4, pp. 361-377, 2011.

[10] P. Grimshaw, J. M. Calo, and G. Hradil, "Cyclic electrowinning/precipitation (CEP) system for the removal of heavy metal mixtures from aqueous solutions," Chemical Engineering Journal, vol. 175, pp. 103-109, 2011.

[11] I. C. Agarwal, A. M. Rochon, H. D. Gesser, and A. B. Sparling, "Electrodeposition of six heavy metals on reticulated vitreous carbon electrode," Water Research, vol. 18, no. 2, pp. 227-232, 1984.

[12] I. Sheet, A. Kabbani, and H. Holail, "Removal of heavy metals using nanostructured graphite oxide, silica nanoparticles and silica/graphite oxide composite," Energy Procedia, vol. 50, pp. 130-138, 2014.

[13] A. Farsi, N. Javid, and M. Malakootian, "Investigation of adsorption efficiency of $\mathrm{Cu}^{2+}$ and $\mathrm{Zn}^{2+}$ by red soil and activated bentonite from acid copper mine drainage," Desalination and Water Treatment, vol. 144, pp. 172-184, 2019.

[14] M. Y. A. Mollah, R. Schennach, J. R. Parga, and D. L. Cocke, "Electrocoagulation (EC) - science and applications," Journal of Hazardous Materials, vol. 84, no. 1, pp. 29-41, 2001.

[15] J. Lu, Y. Li, M. Yin, X. Ma, and S. Lin, "Removing heavy metal ions with continuous aluminum electrocoagulation: a study on back mixing and utilization rate of electro-generated $\mathrm{Al}$ ions," Chemical Engineering Journal, vol. 267, pp. 86-92, 2015.

[16] E. Bazrafshan, K. A. Ownagh, and A. H. Mahvi, "Application of electrocoagulation process using iron and aluminum electrodes for fluoride removal from aqueous environment," E-Journal of Chemistry, vol. 9, no. 4, pp. 2297-2308, 2012.

[17] E. Bazrafshan, L. Mohammadi, A. Ansari-Moghaddam, and A. H. Mahvi, "Heavy metals removal from aqueous environments by electrocoagulation process-a systematic review," Journal of Environmental Health Science and Engineering, vol. 13, pp. 1-16, 2015.

[18] M. Mollah, P. Morkovsky, J. Gomes, M. Kesmez, J. Parga, and D. Cocke, "Fundamentals, present and future perspectives of electrocoagulation," Journal of Hazardous Materials, vol. 114, no. 1-3, pp. 199-210, 2004.

[19] B. Khaled, B. Wided, H. Béchir, E. Elimame, L. Mouna, and T. Zied, "Investigation of electrocoagulation reactor design parameters effect on the removal of cadmium from synthetic and phosphate industrial wastewater," Arabian Journal of Chemistry, vol. 12, no. 8, pp. 1848-1859, 2019.

[20] A. E. Yilmaz, S. Bayar, R. Boncukcuoglu, and B. A. Fil, "Removal of cadmium by electrocoagulation and a cost evaluation," Ekoloji, vol. 21, no. 85, pp. 26-33, 2012.

[21] É. Fekete, B. Lengyel, T. Cserfalvi, and T. Pajkossy, "Electrochemical dissolution of aluminium in electrocoagulation experiments," Journal of Solid State Electrochemistry, vol. 20, no. 11, pp. 3107-3114, 2016.

[22] M. Prica, S. Adamovic, B. Dalmacija et al., "The electrocoagulation/flotation study: the removal of heavy metals from the waste fountain solution," Process Safety and Environmental Protection, vol. 94, pp. 262-273, 2015.

[23] M. Al-Shannag, Z. Al-Qodah, K. Bani-Melhem, M. R. Qtaishat, and M. Alkasrawi, "Heavy metal ions removal from metal plating wastewater using electrocoagulation: kinetic study and process performance," Chemical Engineering Journal, vol. 260, pp. 749-756, 2015.

[24] S. Garcia-Segura, M. M. S. G. Eiband, J. V. de Melo, and C. A. Martínez-Huitle, "Electrocoagulation and advanced electrocoagulation processes: a general review about the fundamentals, emerging applications and its association with other technologies," Journal of Electroanalytical Chemistry, vol. 801, pp. 267-299, 2017.

[25] B. Serpaud, R. Al-Shukry, M. Casteignau, and G. Matejka, "Adsorption des métaux lourds $(\mathrm{Cu}, \mathrm{Zn}, \mathrm{Cd}$ et $\mathrm{Pb})$ par les sédiments superficiels d'un cours d'eau: rôle du $\mathrm{pH}$, de la température et de la composition du sédiment," Revue Des Sciences De L'Eau, vol. 7, p. 343, 1994.

[26] S. Chellam, "Aluminum electrocoagulation and electroflotation pretreatment for microfiltration: fouling reduction and improvements in filtered water quality," in Proceedings of the Desalination and Water Purification Research Program, pp. 1-114, Denver, CO, USA, February 2014.

[27] I. Kabdaşl1, I. Arslan-Alaton, T. Ölmez-Hancı, and O. Tünay, "Electrocoagulation applications for industrial wastewaters: a critical review," Environmental Technology Reviews, vol. 1, pp. 2-45, 2012.

[28] U. T. Un and S. E. Ocal, "Removal of heavy metals (Cd, Cu, $\mathrm{Ni}$ ) by electrocoagulation," International Journal of Environmental Science and Development, vol. 6, no. 6, pp. 425-429, 2015.

[29] B. Lekhlif, L. Oudrhiri, F. Zidane, P. Drogui, and J. F. Blais, "Study of the electrocoagulation of electroplating industry wastewaters charged by nickel (II) and chromium (VI)," Journal of Materials and Environmental Science, vol. 5, pp. 111-120, 2014.

[30] V. Khandegar and A. K. Saroha, "Electrocoagulation for the treatment of textile industry effluent-a review," Journal of Environmental Management, vol. 128, pp. 949-963, 2013. 
[31] M. F. Ashby and D. R. H. Jones, "Wet corrosion of materials," in Engineering Materials 1, pp. 385-400, Elsevier, Amsterdam, Netherlands, 2012.

[32] M. Mechelhoff, G. H. Kelsall, and N. J. D. Graham, "Electrochemical behaviour of aluminium in electrocoagulation processes," Chemical Engineering Science, vol. 95, pp. 301-312, 2013.

[33] M. Kobya, M. Bayramoglu, and M. Eyvaz, "Techno-economical evaluation of electrocoagulation for the textile wastewater using different electrode connections," Journal of Hazardous Materials, vol. 148, no. 1-2, pp. 311-318, 2007.

[34] J. Sarrazin and M. Verdaguer, L'oxydoreduction: Concepts et Expériences, Ellipses Marketing, Worthing, UK, 1991.

[35] A. Vázquez, I. Rodríguez, and I. Lázaro, "Primary potential and current density distribution analysis: a first approach for designing electrocoagulation reactors," Chemical Engineering Journal, vol. 179, pp. 253-261, 2012.

[36] M. Malakootian and N. Yousefi, "The efficiency of electrocoagulation process using aluminum electrodes in removal of hardness from water," Iranian Journal of Environmental Health Science \& Engineering, vol. 6, pp. 131-136, 2009.

[37] L. K. Wang, Y.-T. Hung, and N. K. Shammas, Physicochemical Treatment Processes, Humana Press, Totowa, Ni, USA, 2005.

[38] E. V. Vidya Vijay, M. Jerold, M. S. Ramya Sankar, S. Lakshmanan, and V. Sivasubramanian, "Electrocoagulation using commercial grade aluminium electrode for the removal of crystal violet from aqueous solution," Water Science and Technology, vol. 79, no. 4, pp. 597-606, 2019.

[39] M. V. Rendón, J. A. Calderón, and P. Fernández, "Evaluation of the corrosion behavior of the al-356 alloy in $\mathrm{NaCl}$ solutions," Química Nova, vol. 34, no. 7, pp. 1163-1166, 2011.

[40] A. S. Gnedenkov, S. Sinebryukhov, D. Mashtalyar, I. Vyaliy, V. Egorkin, and S. Gnedenkov, "Corrosion of the welded aluminium alloy in $0.5 \mathrm{M} \mathrm{NaCl}$ solution. Part 1: specificity of development," Materials, vol. 11, pp. 1-17, 2018.

[41] R. T. Foley, "Localized corrosion of aluminum alloys-a review," Corrosion, vol. 42, no. 5, pp. 277-288, 1986.

[42] Y. Koumya, R. Idouhli, M. Khadiri et al., "Pitting corrosion and effect of Euphorbia echinus extract on the corrosion behavior of AISI 321 stainless steel in chlorinated acid," Corrosion Reviews, vol. 37, no. 3, pp. 259-271, 2019.

[43] Y. Koumya, R. Idouhli, M. E. Khadiri et al., "Semiconducting behavior and kinetics of passive film growth on AISI 321 stainless steel in sulfuric acid," Corrosion Reviews, vol. 38, no. 1, pp. 87-98, 2020.

[44] P. Holt, G. Barton, and C. Mitchell, "Electrocoagulation as a wastewater treatment," in Proceedings of the Third Annual Australian Environmental Engineering Research Event, pp. 1-6, Castlemaine, Victoria, 1999.

[45] M. Trueba and S. P. Trasatti, "Electrochemical approach to repassivation kinetics of $\mathrm{Al}$ alloys: gaining insight into environmentally assisted cracking," Corrosion Reviews, vol. 33, no. 6, pp. 373-393, 2015.

[46] C. E. Vanderzee and H. J. Dawson, "The stability constants of cadmium chloride complexes: variation with temperature and ionic Strength1," Journal of the American Chemical Society, vol. 75, no. 22, pp. 5659-5663, 1953.

[47] M. Borsari, Cadmium: coordination chemistry, Encyclopedia of Inorganic and Bioinorganic Chemistry, John Wiley \& Sons, Ltd., Hoboken, NJ, USA, 2014.

[48] R. P. Mason, Trace Metals in Aquatic Systems, John Wiley \& Sons, Ltd., Hoboken, NJ, USA, 2013.

[49] M. Bharath and B. M. Krishna, "A Review of electrocoagulation process for wastewater treatment," International
Journal of ChemTech Research, vol. 11, no. 3, pp. 289-302, 2018.

[50] C.-H. Huang, L. Chen, and C.-L. Yang, "Effect of anions on electrochemical coagulation for cadmium removal," Separation and Purification Technology, vol. 65, no. 2, pp. 137-146, 2009.

[51] M. Kobya, E. Demirbas, N. U. Parlak, and S. Yigit, "Treatment of cadmium and nickel electroplating rinse water by electrocoagulation," Environmental Technology, vol. 31, no. 13, pp. 1471-1481, 2010.

[52] S. Gupta, P. Pandotra, A. P. Gupta et al., "Volatile (As and Hg) and non-volatile $(\mathrm{Pb}$ and $\mathrm{Cd})$ toxic heavy metals analysis in rhizome of Zingiber officinale collected from different locations of North Western Himalayas by Atomic Absorption Spectroscopy," Food and Chemical Toxicology, vol. 48, no. 10, pp. 2966-2971, 2010.

[53] G. Yildirim and Ş. Tokalioğlu, "Heavy metal speciation in various grain sizes of industrially contaminated street dust using multivariate statistical analysis," Ecotoxicology and Environmental Safety, vol. 124, pp. 369-376, 2016.

[54] E. Venturini, I. Vassura, L. Ferroni et al., "Bulk deposition close to a municipal solid waste incinerator: one source among many," Science of The Total Environment, vol. 456-457, pp. 392-403, 2013. 